\title{
Faculty Appointments and Scholarly Activity: A Changing of the Guard?
}

\author{
Randall G. Bowden, PhD \\ Department of Education Administration and Research \\ 6300 Ocean Dr., Unit 5818, Faculty Center 212 \\ Texas A\&M University - Corpus Christi \\ Corpus Christi, TX 78412-5818, U.S.A.
}

Tel: 1-361-825-6034Ｅ-mail: randall.bowden@tamucc.edu

\author{
Lynn Gonzalez, $\mathrm{PhD}$ \\ Department of Accounting, Concordia College \\ 901 8th St. S. Moorhead, MN 56562, U.S.A.
}

Tel: 1-701-741-5000Ｅ-mail: gonzalez.lynn@yahoo.com

Received: September 5, 2012

Accepted: September 28, $2012 \quad$ Online Published: October 15, 2012

doi:10.5430/ijhe.v1n2p166

URL: http://dx.doi.org/10.5430/ijhe.v1n2p166

\begin{abstract}
American institutions of higher education are experiencing a rapid change in academic staffing, leaving the tenure model for a more flexible, contingent workforce. Nearly two in five of all full-time instructional staff holds non-tenure-eligible positions as term-limited academic appointments. This study compared faculty appointment types by traditional areas of teaching, research, and service by utilizing the National Study of Postsecondary Faculty 2004 data. Statistical results indicated tenured and tenure-track faculty far outperform contingent faculty in all three traditional areas: teaching, research, and service. This is of substantial concern. Since contingent faculty are rapidly increasing, it brings into question who is doing the work and how it affects production in areas of teaching, research, and service.
\end{abstract}

Keywords: Faculty, Teaching, Research, Service, Contingent, Scholarly activity

\section{Introduction}

American institutions of higher education are experiencing a rapid change in academic staffing, leaving the tenure model for a more flexible, contingent workforce. Nearly two in five of all full-time instructional staff holds non-tenure-eligible positions as term-limited academic appointments (Schuster \& Finkelstein, 2006). According to the Integrated Postsecondary Education Data System (IPEDS) Fall Staff Survey for 2003, among 630,000 full-time faculty, $55.1 \%$ hold time-limited appointments. This includes $20.3 \%$ of faculty who are in a tenure-track eligible position, plus $34.8 \%$ of faculty who are in non-tenure-eligible positions (Schuster \& Finkelstein, 2006).

The number of tenure-track positions has been in steady decline. Data from the National Study of Postsecondary Faculty (NSOPF: 99) revealed that across degree-granting postsecondary institutions, approximately one-half (48\%) of full-time faculty had tenure, $19 \%$ of full-time faculty were in tenure-track positions but had not received tenure, and $20 \%$ were not in tenure-track positions. Additionally, about $12 \%$ of all full-time faculty worked at institutions with no tenure system (Berger, Kirshstein, \& Rowe, 2001). This is a dramatic shift from a 1969 landmark Carnegie national survey of faculty that showed only about $3 \%$ of full-time faculty were non-tenure-track (Schuster, 2003).

Tenure has been widely accepted as "the uniform model for academic employment since 1940" (Gappa, Austin, \& Trice, 2005, p. 34). In the past, the majority of faculty were hired full-time on one career ladder (tenure-track). Tenure status was awarded when they met their institutions' promotion criteria by demonstrating high performance in teaching, research, and service (Bland, Center, Finstad, Risbey, \& Staples, 2006). Tenure status can provide an enduring relationship between faculty and their institutions by a contractual guarantee of career-long job service (Allen, 2000; Gappa et al., 2005). 
However, the guard is rapidly changing. With current trends towards hiring faculty off the tenure-track system, it raises the issue of how the traditional activities of teaching, research, and service are affected by contingent faculty appointments. Teaching, research, and service are often referred to as the triad or the three-legged stool that define the activities of university faculty (Popovich \& Abel, 2002). Contingent faculty are referred to as faculty who are not typically on a tenure-track system (Benjamin, 2003; Gappa et al., 2005; Umbach, 2007). Although previous research examined the increasing use of contingent faculty across the academy, little work has been done to compare actual performance in teaching, research, and service among contingent, tenured, tenure-track, and no tenure system faculty. This research compared teaching, research, and service productivity among faculty as reported in the National Study of Postsecondary Faculty (NSOPF: 04).

\section{Theoretical Framework}

The primary activities of faculty are often described in terms of teaching, research, and service (Paulsen \& Feldman, 1995). The American Association of University Professors (AAUP) described this traditional framework in light of tenure as "freedom of teaching, research, and extramural activities" (1940 Statement of Principles, ๆ 5). Teaching, research, and service have endured through the years as the standard of faculty work in a postsecondary setting, although their value may be threatened. The theoretical framework for this study was based on the traditions of higher education for teaching, research, and service: (a) "to provide general instruction to the students" (teaching); (b) "to promote inquiry and advance the sum of human knowledge" (research); and (c) "to develop experts for various branches of the public" (service) (Seligman \& Lovejoy, 1915, p. 295). Although, service may more accurately be described as "work based on the faculty member's professional expertise that contributes to the mission of the institution" (Lynton, 1995, p. 17).

The traditional model of faculty work in American institutions of higher education is experiencing a rapid change in academic staffing, leaving the tenure model for a more flexible, contingent workforce. The increased hiring of part-time and full-time, non-tenure-track faculty members is well-documented (Baldwin \& Chronister, 2001; Gappa \& Leslie, 1993; Gappa et al., 2007). But, how effective this change is in the traditional work of faculty is questioned.

\section{Purpose of the Study}

The composition of higher education's most valuable asset, the faculty, is being dramatically altered. As a result of the changes in faculty appointment status, the essential work of faculty is being transformed (Schuster \& Finkelstein, 2006; Singell, Lillydahl, \& Singell, 1996). Because of the transformation of the faculty environment, it raises concerns about the effectiveness of activities. There is even a perception that academic quality is threatened by the increasing use of contingent faculty because of the erosion of the tenure system (Haeger, 1998).

Given this dramatic shift in faculty employment, the purpose of this study was to examine how changes in faculty appointments relate to the production of teaching, research, and service. The independent variable refers to faculty appointments in four areas: (a) tenure; (b) tenure-track; (c) contingent faculty; and (d) no tenure system. Their impact is examined in light of the traditional framework of faculty work on three dependent variables: (a) teaching; (b) research; and (c) service. Contingent faculty are often categorized broadly in terms of "part-time, contract, adjunct, clinical, research, visiting, lecturer, or senior lecturer" (Thedwell, 2008, p. 11). Although there has been considerable concern for the erosion of tenured and tenure-track positions, there has not been an in-depth, empirical investigation of how it impacts the production of teaching, research, and service.

\section{Literature Review}

The nature of faculty appointments has been dramatically altered over the past 30 years. Institutions of higher education are experiencing a rapid modification in academic staffing, leaving the tenure model for a growing contingent workforce. Between 1975 and 1995, the number of full-time tenure-ineligible faculty increased by $93 \%$ (Umbach, 2007). Researchers are concerned about the decrease in tenured faculty positions and how it impacts the quality of education. "Faculty and their work are the heart, and thus determine the health, of every college and university and have a lasting impact on the many lives they touch" (Gappa et al., 2005, p. 32). Based on the growing trend of colleges and universities to eliminate tenure-track positions and replace them with non-tenure-track faculty and adjunct faculty, there is a perception among many in the academy that academic quality is threatened (Curtis \& Jacobe, 2006; Haeger, 1998; Jaeger, 2008; Johnson, 2011; Ochoa, 2011; Roworth, 1997; Schuster, 2003; Townsend, 2003).

\subsection{Teaching}

Teaching is described as communication and interaction between a teacher and a student about a subject matter (Davis, 1993). Fink (2003) related teaching as the integration of subject matter knowledge, instructional design, 
teacher-student interaction, and course management. McKeachie and Svinicki (2006) focused on teaching as student learning, which involves faculty goals, textbooks, syllabus, lesson plans, technology, student activities, and teaching method. In a more visceral approach to teaching, Bain (2004) described it as helping "students learn in ways that made a sustained, substantial, and positive influence on how those students think, act, and feel" (p. 5). In short, teaching involves faculty interaction with students inside and outside the classroom. Although views of teaching may vary, this study refers to teaching according to the work established by the National Study of Postsecondary Faculty (NSOPF: 04) in two categories: (a) structure; and (b) experience. Structure refers to number of classes, weeks, credits, students, and hours taught, as well as graduate or professional courses taught. Experience addresses course activities as use of multiple choice questions in exams, essays, short answer exams, number of writing assignments, multiple drafts for writing assignments, oral presentations, group/team work, peer evaluations, service/community projects, and faculty use of websites.

Faculty teaching requirements vary by type of institution. Huber (1997), consistent with Davis' view of teaching, found that during the Fall of 1996, community college faculty reported spending around 15 hours a week teaching undergraduates, where faculty at baccalaureate and master's institutions reported spending 10 hours a week. At the two-year institution level where contingent faculty (adjunct) comprise up to $70 \%$ of the faculty according Jaeger (2008) and up to $83 \%$ according to Thedwell (2008), Ried (2008) found that as the number of part-time faculty increases, graduation rates decrease. Interestingly, faculty at doctoral institutions and research institutions reported just 7.5 hours and 6 hours per week, respectively (Huber 1997). Using the number of hours spent on classroom teaching per week is commonly used to measure teaching (Allen, 1996; Colbeck, 2001; Fairweather, 2002, 2005). When Ochoa (2011) examined the impact of contingent faculty across higher education, she reported that non-tenure track faculty interacted with students less than their tenure-track peers both inside and outside the classroom. Additionally, after examining the Faculty Survey of Student Engagement data, Umbach (2007) concluded that contingent faculty spend less time with students, use less engaging teaching techniques, prepare less for class, and expect less from students than tenure and tenure-track students. The process of what faculty do that constitutes teaching is easy to demonstrate, but there is not a tangible product to be used as a measure of effective teaching.

Tenure-track faculty are expected to teach, however outstanding teaching will not by itself guarantee tenure (Park, 1996). Tenure-track faculty, generally, are rewarded more highly for research publications than for teaching. However, in the Carnegie Foundation for the Advancement of Teaching's National Survey of Faculty from 1969 to 1989, the majority of faculty polled agreed that "teaching effectiveness, not publications, should be the primary criterion for promotion" (Rosenthal, Cogan, Marshall, Meiland, Wion, \& Molotsky, 1994). Neverthelss, it is not just tenure that is at stake. According to Johnson (2011), contingent status impacts job satisfaction and academic quality. Since contingent faculty often lack job stability, they also frequently lack support services, office area, employment benefits, and development opportunities, which can interfere with their work and lead to dissatisfaction. Johnson continued to report a lower quality of academic instruction and less quality of impact on students' academic experience as a whole. Ultimately, since contingent faculty are hired primarily for classroom duties, access to them and their involvement in activities outside the classroom make them less accessible to students (Jaeger, 2008). Yet, with the use of more contingent faculty as contract workers, one can begin to seriously question the commitment to teaching and its quality across the academy as a primary work of faculty, which is to provide general instruction to the students. This concern carries over to research, too, where the stakes seem to be even higher.

\subsection{Research}

Research promotes inquiry and advances the sum of human knowledge. It is contributing to the stock of human knowledge and to the intellectual climate of a college or university (Boyer, 1990, p. 17). Research is an activity that results in a finished product, such as a journal article, book, or other creative work that brings prestige to an institution (Park, 1996). It also includes dissemination of one's work through presentations at conferences and workshops, however, these are not typically given as much weight as publishing in peer-reviewed journals for promotion and tenure (Massy \& Wilger, 1995). Publications often replace teaching as the primary faculty role and are an important criterion for promotion and tenure decisions (Blackburn \& Lawrence, 1995). Plus, the primary measure of research activity used in tenure decisions is the number of publications (Allen, 1996; Blackburn \& Lawrence, 1995; Bland et al., 2006; Fairweather, 2005). Although the number of publications is used to assess faculty productivity, it is not evidence of research quality (Colbeck, 2004), thus many in academia are concerned with the pressure to publish in order to be productive (De Rond \& Miller, 2005; Euben, 2002; Neill, 2008; and Parker, Guthrie, \& Gray, 1998). For this study the National Study of Postsecondary Faculty (NSOPF: 04) referred to research in the number of: articles or creative works in referred and non-referred journals; reviews of books, articles, 
creative works, chapters in edited books; textbooks other books, monographs, and client reports; presentations at conferences or workshops; career exhibitions or performances; and patents, software, products, or other works.

Although teaching, research, and service are considered for tenure decisions, research tends to dominate the decision process. Green (2008) looked at the issue from the perspective of 130 deans and directors of social work programs. The most important factor for tenure was research, followed closely by teaching, and service as a distant third. Although this tends to reflect findings in other studies, Green concluded that the focus on research is becoming more prevalent for faculty to obtain tenure in programs with nondoctoral degrees. In business education Alshare, Wenger, and Miller (2007) looked at how deans weighted teaching, research, and service for tenure and promotion. Service was the lowest at $9.5 \%$ followed by teaching at $32.5 \%$ with research as the most important at $58 \%$. However, the data could be somewhat skewed as only deans from programs that had AACSB accreditation or were AACSB candidates were surveyed. Standard two for accreditation with AACSB states that research intellectual contributions are essential for the advancement of knowledge (Eligibility Procedures and Accreditation Standards for Business Accreditation AACSB International, 2012). However, the sentiment about the importance of research toward tenure tends to be reflected across institutions. At 135 colleges and universities awarding promotion, tenure, and merit pay, Terpstra and Honoree (2009) found that institutions favored research for promotion, tenure, and merit pay decisions with service weighted at the bottom. Much of this research, though, needs to be tempered with the perspective of an institution's mission. As Green (2008) related, an institution with a mission emphasizing teaching, service and teaching generally have more weight for tenure than research, however, research is still accepted as a highly value-added commodity.

Faculty, who engage in teaching and research, are referred to as a teacher-scholar or an active scholar (Fender, Taylor, \& Burke, 2011). They are expected to be productive in both activities. From the work of Becker and Kennedy (2006) 150 active researchers stated teaching is important because it informs their research. Becker and Kennedy implied that for top scholars teaching and research are complementary of each other. According to Fairweather (2002), the belief in the teacher-scholar rests on the tenet that the best scholars are those who use research to supplement teaching and vice versa. However, the relationship between teaching and research does not reveal positive findings toward the teacher-scholar model (e.g., Feldman, 1987; Hattie \& Marsh, 1996). Ultimately, faculty who taught less and published more received the highest average salaries regardless of institution type or academic discipline (Fairweather, 2002, 2005). Thus, eliminating tenured and tenure-track positions could threaten not only highly prized work but the traditional theoretical framework guiding faculty work in this area, which is to promote inquiry and advance the sum of human knowledge. Even though teaching is thought to be the primary role of faculty and although there is concern among many academics to tie teaching and research more closely together (e.g., Burke \& Rau, 2011; Dawson \& Burke, 2008; Fukami, 2007), teaching is rewarded less than research. Service is not even as highly regarded as teaching, yet is a vital component the traditional framework.

\subsection{Service}

Service formally became part of the mission of higher education through the Morrill Acts of 1862 and 1890 (Scott, 2006). However, what is defined as service is often nebulous, although Neumann and Terosky (2007) summarized its function: (a) broad-ranging, eclectic, variable, and thereby under-defined; (b) increasingly prominent in faculty careers but under-appreciated and under-researched; (c) in tension between content and context perspectives; and (d) comprising new work for professors at (or approaching) midcareer, a stage that is itself expansive and under-defined. They performed a three year qualitative study of recently tenured faculty to see if service increased after tenure. They found that recently tenured faculty reported noticeable increases in service, although it is not a well defined form of faculty work. The National Study of Postsecondary Faculty (NSOPF: 04) defined service as number of hours spent on: thesis, dissertation, or comprehensive exams and certification committees; administrative and committee work; student advising; and office hours.

Service seems to be the catchall name for everything that cannot be identified as teaching or research (Blackburn \& Lawrence, 1995). Attempts have been made to describe it as "work based on the faculty member's professional expertise that contributes to the mission of the institution" (Lynton, 1995, p. 17). Faculty serve the institution by participation on curriculum committees, in departmental duties, and student advising. Additionally, faculty serve the larger community through technical assistance, policy analysis, and other extension services (Lynton \& Elman, 1987).

Unlike the literature for teaching and research, there is little empirical work on faculty related to service. Many tenure decisions are not based on it, although faculty are expected to engage in service. Therefore, many faculty believe that service is an activity not highly rewarded (Dilts, Haber, \& Bialik, 1994). Florestano and Hambrick (1984) 
suggested three reasons why service is not often used in tenure and promotion decisions: (a) it is difficult to define with little to no standards to differentiate between professionally related service with that which is not; (b) there are no good measures for evaluation; (c) it is not highly regarded by both faculty and administrators. Even though service was referenced in the previous section in conjunction with the value of research for promotion and tenure, the findings of Luchs, Seymore, and Smith (2012) underscore the value of service. In a study of 115 business faculty, they found that service was just as important in smaller institutions as it was in medium sized and large ones, but findings indicated service was rated as slightly to moderately important, overall, when compared to teaching and research. Green (2008) reiterated the diminishing role of service in tenure and promotion decisions for the twenty-first century, including a diminishing role for teaching.

Even though service is not as highly valued as teaching and research on most campuses, it adds tremendously to the work of the academic enterprise. A faculty member's professional expertise can lend itself to the success of colleges and universities. Yet, as the tenure system continues to erode, its impact needs to be assessed in light of the work of faculty: (a) to provide instruction; (b) to promote inquiry and advance knowledge; and (c) and to provide professional expertise (Lynton, 1995; Seligman \& Lovejoy, 1915). The current investigation examined faculty appointments and their impact on the foundation of faculty work.

\section{Research Questions}

This study relied on faculty appointment types and their impact on the traditional roles of teaching, research, and service productivity. Using data from the National Center for Education Statistics' (NCES) National Survey of Postsecondary Faculty of 2004 (NSOPF:04) three primary research questions were considered: (a) What is the relationship between faculty appointment and teaching in terms of structure and experience?; (b) What is the relationship between faculty appointment and recent research activities?; and (c) What is the relationship between faculty appointment and service?

Although there were only three research questions, there were multiple analyses for each one as operationalized by the NSOPF survey. Generally, faculty appointments were defined as (a) tenure; (b) tenure-track; (c) contingent or not on tenure-track; and (d) no tenure system. Teaching was defined as structure and experience that facilitated interaction between a teacher and a student. Research referred to an activity that resulted in a finished product-a journal article, book, or other creative work. Service pertained to committee work, office hours, and meeting with students as described by the NSOPF survey.

\section{Methods}

This study accessed data from the National Center for Education Statistics' (NCES) National Survey of Postsecondary Faculty of 2004 (NSOPF: 04). The NCES is located within the U. S. Department of Education and the Institute of Education Sciences. It is the primary federal entity for the collection and analysis of data related to the condition of American education and education activities internationally. The full-scale sample of the NSOPF consisted of 35,630 faculty and instructional staff from 980 sampled institutions in the United States and the District of Columbia. A reported response rate of $76 \%$ resulted in the participant size of 26,110 faculty and instructional staff (NCES, 2006) from stratifying 3,396 institutions in the U.S. on the basis of the highest degree offered and the amount of federal research dollars they received.

The NSOPF: 04 was designed to provide nationally represented profiles of faculty and instructional staff at public and private not-for-profit two-year and four-year institutions. It provides national benchmarks for faculty productivity, faculty workload, and information on institutional policies and practices that affect faculty. The survey asked participants to respond to demographic information; academic and professional background; employment history and current employment status, including rank and tenure; workload; publications; job satisfaction and attitudes; and career and plans for retirement.

This study used the Data Analysis System (DAS) developed for the public. The DAS is a Windows based software application that provides public access to the NSOPF survey data. It allows users to produce tables drawn from NSOPF survey items, including straight counts, percentages, means, and correlation coefficients. The DAS has analytic capabilities to estimate covariance analyses using both weighted least squares regression and logistic regression. The Data Analysis System (DAS) was used to access the NSOPF: 04 survey data to perform several statistical analyses to examine how changes in faculty appointment were related to activities of teaching, research, and service. The research did not distinguish among Carnegie classifications, which could indicate differences of faculty production due to institutional type. Although classification categories were not controlled for, across all institutions tenured and tenure-track faculty out performed contingent faculty in teaching, research, and service. The 
current concern is that fewer and fewer tenure and tenure-track positions are available, thus, how might it affect work production in the traditional roles of teaching, research, and service?

\section{Results}

Overall, the results showed a dramatic gap among faculty appointments and involvement in teaching, research, and service. Because of these gaps, its raises even greater concern about the erosion of tenure and tenure-track positions, which will be addressed below in the discussion. But first, an overview of the results is presented.

Research question one looked at the relationship of faculty appointment and teaching. Teaching was described by the NSOPF in several areas, such as number of students, credits, classes, weeks taught, level of student, teaching assistants to measure teaching structure, types of assignments, strategies, communication, and evaluations to measure teaching experience. Overall, faculty with tenure or on tenure-track provided more teaching services to students than those who were not.

Teaching structure varied by faculty appointment. For example, it was statistically significant among contingent, non-tenured system, tenured, and tenure-track faculty for number of courses taught $(\mathrm{M}=1.60, \mathrm{M}=2.70, \mathrm{M}=2.50$, $\& \mathrm{M}=2.50$, respectively). The Pearson's chi-square test of independence shows there is a relationship between faculty appointment and the number of classes the faculty taught for credit: $\chi^{2}(9)=108.04, p<.001$. Although, this may be due to the type of appointment itself, as many contingent faculty are part-time and have other job responsibilities away from higher education. This raises concern, then, for effects teaching structure has on students as provided by part-time faculty.

Also, tenured and tenure-track faculty reported having more students in their classes. The Pearson's chi-square test of independence shows there is a relationship between faculty appointment and the number of students in each class: $\chi^{2}(9)=36.17, p<.001$ (tenured $M=36.70 \&$ tenure-track 32.70). Thus, they reach more students according to the traditional framework to provide general instruction. They interact with students significantly in other areas as well. The Pearson's chi-square test of independence shows there is a relationship between faculty appointment and the number of classes the faculty taught for credit: $\chi^{2}(9)=108.04, p<.001$. Tenured and tenure-track faculty tend to teach more higher level courses $\left(\chi^{2}(9)=79.41, p<.001\right)$, which leaves one to wonder the type of impact the majority of the nation's students are receiving at the undergraduate level. Table 1 provides an overview of the gaps among appointment and teaching structure categories.

Additional analyses demonstrated gaps in experience besides those in structure. Table 2 summarizes the gaps. For example, tenured and tenure-track faculty were less likely to use standardized testing as teaching methods, such as multiple choice and true false. They engage students in other learning activities, such as papers, and essays, oral presentations, groups and teams, and other instructional duties, as well as individual contact with students. Logistic regression analysis results for tenured faculty were $(\beta=-0.166, S E=.020, t=-8.322, p<.001)$; on tenure-track were $(\beta=-0.086, S E=.015, t=-5.623, p<.001)$; and not on tenure-track was $(\beta=-0.119, S E=.021, t=-5.788, p<.001)$. Given a negative regression coefficient $(\beta)$ the inverse odds ratios were reported. The inverse odds ratio for tenured faculty was 2.16 . This indicated tenured faculty were 2.16 times less likely to use multiple-choice midterm or final exams than faculty not tenured-no tenure system. The inverse odds ratios for faculty on tenure-track and not on tenure-track were 1.74 and 1.67 , respectively. Similarly, these faculty were close to twice as likely not to use multiple-choice midterm or final exams than faculty not tenured-no tenure system. Another way to interpret the inverse odds ratio is those faculty not tenured-no tenure system were about two times more likely to use multiple-choice midterm or final exams than other faculty.

With both teaching structure and teaching experience, tenured and tenure-track faculty tended to have more teaching interaction with students than their counterparts. However, there is a shift in areas of service-type learning and web work as these may be a function of adjuncts being more established in the community, as well as teaching more online courses and not having campus office space.

Research question two examined the relationship between faculty appointment and research activities. Research activities according to the NSOPF include items, such as refereed publications, non-refereed publications, books, monographs, reports, presentations, performances, patents, and other products. Tenured and tenure-track faculty out-performed other faculty on major measures of research.

Overall, the faculty as a whole published a mean of 1.4 articles and creative works in refereed journals or juried media over a two year period. Tenured faculty reported the highest mean number of publications $(M=2.70 ; S E$ $=.06)$, followed by faculty on tenure-track $(M=2.10 ; S E=.05)$. Both faculty not on tenure-track $(M=0.70 ; S E$

$=.02)$ and not tenured-no tenure system $(M=0.50 ; S E=.05)$ resulted in a mean of less than one publication in the 
past two years. Tenured faculty $(19.4 \%)$ and tenure-track (15.5\%) reported at least five publications in the previous two years. Those faculty not on tenure-track or not tenured-no tenure system had lower percentages reporting $4.6 \%$ and $3.1 \%$, respectively. Less than half of tenured $(46.7 \%)$ and on tenure-track $(42.6 \%)$ reported no recent published articles in refereed journals. A much higher percentage of faculty not on tenure-track (78.8\%) and not tenured-no tenure system $(83.4 \%)$ reported not having any recent publications.

The results in the category of one to two recent publications are the most fascinating. Tenured faculty (20.8\%) and on tenure-track $(28.1 \%)$ reported one to two publications. The results were much lower for faculty not on tenure-track (12.5\%) and not tenured-no tenure system (10.6\%). The Pearson's chi-square test of independence showed there was a relationship between faculty appointment and the number of articles and creative works published in refereed journals or juried media in the last two years: $\chi^{2}(9)=166.72, p<.001$.

There are similar patterns of significance in other categories of research activities, as Table 3 indicates. In all major areas of research activity, tenure and tenure-track faculty promoted inquiry and advanced the sum of human knowledge more frequently than their counterparts.

Research activities are a highly valued function of faculty work to promote inquiry and advance the sum of human knowledge. The role and function of contingent faculty must be critically considered as to how it serves institutions. Whereas some functions of teaching favor contingent faculty, research activities offer a different view. With the exception of performances and patents, contingent faculty fall well behind others in the major areas of research concern. We question how effective institutions really are as they attempt to promote inquiry and advance the sum of human knowledge, if contingent faculty are going to continue to increase.

Research question three measured the relationship between faculty appointment and service. According to the NSOPF survey, service includes items, such as number of hours on thesis and dissertation committees, number of hours on administrative committees, as well as student advising and office hours. Here, again, tenure and tenure-track faculty provided a stronger commitment to the traditional work of faculty.

For example, the weighted percentage distribution and standard errors for number of hours per week spent on administrative committee work are better for tenured and tenure-track faculty than contingent ones. Tenured (86.7\%) and tenure-track faculty (83.1\%) reported working on administrative committees. These percentages are much higher compared to those not on tenure-track (28.3\%) and not tenured-no tenure system (51.7\%). The Pearson's chi-square test of independence shows there is a relationship between faculty appointment and the number of hours per week spent on administrative committee work: $\chi^{2}(9)=385.15, p<.001$. It was also statistically significant that tenured and tenure-track faculty spent more time advising $\left(\chi^{2}(9)=203.11, p<.001\right)$ and had more office hours $\left(\chi^{2}(9)=\right.$ $132.82, p<.001)$. Table 4 illustrates this.

The only area not statistically significant was thesis and dissertation work. This could be due to type of institution, as not all colleges and universities have graduate level projects of this nature. Nevertheless, although service is not valued as highly an activity as teaching or research, it does provide valuable contributions across institutions and the academy.

Overall, the results indicated tenured and tenure-track faculty out-performed other types of faculty appointments according to production measurements. Faculty appointment makes a significant impact on the traditional framework of activities of teaching, research, and service. Since tenured and tenure-track faculty positions are decreasing, yet traditional faculty production is significant with tenured and tenure-track faculty, the results have crucial consequences across the academy.

\section{Discussion}

This study examined how faculty appointments relate to traditional activities of teaching, research, and service. Trends show that institutions of higher education are experiencing a rapid change in academic staffing, removing the tenure model for a contingent workforce. The traditional model of faculty earning tenure through high standards of teaching, research, and service is being transformed due to contingent faculty appointments and systems with no tenure. Within the midst of this transformation, there is strong evidence it will severely alter the nature of faculty work in several areas.

First, the theoretical framework lays the foundation as teaching provides general instruction to students. The data are split. On the one hand, the literature supports the idea that departments are decreasing the number of full time tenured positions to offer more flexible, part-time positions off the tenure-track (Jacobs, 1998; Rhoades, 1996) due to budgetary constraints and the increasing pressure for tenured and tenure-track faculty for research (De Rond \& Miller, 2005; Euben, 2002; Neill, 2008; \& Parker et al., 1998). On the other hand, this research showed tenured and 
tenure-track faculty teach more courses and more students than their counterparts. But, this could be due to employment standards. With increase use of adjunct faculty, they are usually limited to the number of courses they teach. Additionally, they often have other employment and are not professional educators. They will, however, be taking over more courses currently taught by tenured and tenure-track faculty. As trends show (e.g. Gappa et al., 2007) and as budgets get tighter, it is expected even fewer tenured and tenure-track positions will be available, further threatening the traditional work of faculty.

Second, contingent faculty primarily teach undergraduate courses as supported by the results of this study. The data showed that contingent faculty $(62.5 \%)$ and faculty at institutions that do not have a tenure system $(72.2 \%)$ reported teaching only undergraduate classes (which, admittedly may be due to two-year or baccalaureate institutions), while over half of tenured faculty (54.5\%) and tenure-track faculty $(55.5 \%)$ report teaching only undergraduate level courses. The large proportion of non tenure-track faculty primarily teaching undergraduate level classes may raise questions regarding the type of instruction graduate or professional courses taught and students are receiving in foundation courses. For example, two studies showed that new college students had more than $25 \%$ of their academic credits taught by contingent faculty and students taught by contingent faculty had a reduced likelihood of persisting to the second semester (Harrington \& Schibik, 2004; Jaeger \& Hinz, 2008). Faculty who teach foundation and general education courses can enrich or diminish student learning by the attitudes, beliefs, and skills they have as teachers (Meacham, 2002). With contingent faculty being used to teach foundation courses, and these faculty may be temporary at best, this study questions the commitment institutions have toward the social and intellectual development of students, as well as the process of adequately preparing them for upper division course work and work in their major.

Third, when examining the number of hours of individual instruction, tenured and tenure-track faculty reported spending five or more hours of individual instruction when compared to others. These findings are not surprising given that contingent faculty often lack adequate office space, access to computers on campus, and workshops in the use of teaching with technology. These results showed contingent faculty are less likely to be engaged with students outside of the classroom, consistent with Jaeger (2008). She found that although part-time faculty are often unavailable for advising, committee work, and other non-instructional duties, this is also not part of their assignment. If contingent faculty, particularly part-time, are unavailable for advising, committee work, and other non-instructional duties, this begs the questions: Who will do this type of work and how will it get done?

Fourth, the theoretical framework lays the foundation for faculty research in a traditional manner to promote inquiry and advance the sum of human knowledge. The results of this study showed a tremendous gap between the performance of tenured/tenure-track and contingent faculty. They are not surprising because contingent faculty are often hired to teach courses to allow tenure and tenure-track faculty to teach smaller, higher level courses and provide them more time to engage in research activities (Brand, 2002; Cross \& Goldenberg, 2002; Meyer, 1998). Since contingent faculty do not have a long term commitment from their institutions, it is difficult to expect how replacing tenured and tenure-track faculty with contingent ones will meet research requirements by institutions.

Fifth, publication is a critical aspect of advancing inquiry and promoting the sum of human knowledge. Contingent faculty perform at lower levels than tenure and tenure-track faculty. The use of contingent faculty may make economic sense to administrators, but it raises serious concerns for creating new knowledge and promoting the sum of human knowledge. If these functions are at risk, as this study indicates, it brings into question the direction higher education will take to advance inquiry. This indicates that higher education institutions are becoming a clearing house of information instead of institutions of knowledge creation and advancement. As such, there exists anxiety over who will contribute to the stock of human knowledge and how it will be pursued.

Finally, the theoretical framework provides the importance of service work for faculty to develop experts for various branches of public service. Faculty serve the institution by participating on curriculum committees, in departmental duties, and for student advising. Additionally, faculty serve the larger community through technical assistance, policy analysis, and other extension services (Lynton \& Elman, 1987). The low participation of contingent faculty in administrative committee work is not surprising because contingent faculty are often left out of the administrative committee process and do not participate in institutional and departmental governance (American Association of University Professors, 2003; Brand, 2002). It has been suggested that contingent faculty are often seen as too dependent on administration for continued appointments, therefore tenured faculty resist their participation in faculty governance (Kavanaugh, 2000; Thompson, 2003). Similar to teaching and research, those faculty who are tenured or on tenure-track are doing the service work that contingent faculty are not hired to do. Faculty expertise is needed for 
particular service work and if it is diminishing, the questions is asked, again, who will do the work? Although this study did not examine it, a larger issue may be looming as to what will happen to shared governance?

\section{Implications}

The results showed large gaps between tenured/tenure-track and contingent faculty. These are important as it demonstrates that when faculty have a long term commitment of employment, they tend to be more involved with students and the greater community. Contingent faculty are different from tenured and tenure-track faculty in that their institutions ask for a commitment, while making little or no long-term commitment to them (Curtis \& Jacobe, 2006). Based on the growing trend of colleges and universities to eliminate tenure-track positions and replace them with non-tenure-track faculty and adjunct faculty, there is a perception among those in the academy that academic quality is threatened (Curtis \& Jacobe, 2006; Haeger, 1998; Roworth, 1997; Schuster, 2003; Townsend, 2003).

Contingent faculty, as teachers, threatens the quality of instruction. Teaching involves developing the knowledge, skill, mind, character, or ability or others. It "means not only transmitting knowledge, but transforming and extending it as well" (Boyer, 1990, p. 23-24). This is difficult to do when many contingent faculty are not carried over from one term to another (Harrington \& Schibik, 2004; Jaeger \& Hinz, 2008). With contingent faculty growing in popularity, the inference is that administrative decisions are concerned more about overall organizational efficiency than actual teaching and learning (Finkelstein, 2001).

In addition to the gap in teaching between tenured/tenure-track and contingent faculty, research is affected as well. This study indicated the contributions to promoting inquiry and advancing the sum of human knowledge are diminished with increasing use of contingent faculty. It suggests that not only the work of faculty is threatened but the well-being of institutions is too by a contingent faculty approach (Harcleroad \& Eaton, 2005). Fairweather and Beach (2002) reported the top 88 research universities receive $\$ 35$ to $\$ 405$ million in annual revenue from grants and contracts with a mean of $\$ 130$ million. They stated that even tier II institutions are obtaining more and more funding. It is possible that whatever institutions may think they are saving by utilizing contingent faculty, they may be losing because tenured and tenure-track faculty conduct the majority of research. In other words, these external sources of revenue may diminish, as well, with the reduction of tenured and tenure-track faculty research.

The gap between tenured/tenure-track and contingent faculty continues with service. Tenure and tenure-track faculty complete the bulk of academic work on committees. Additionally, they provide service to the community by offering consulting, speaking engagements, and volunteer work. Because these service activities are a major part of college and university operations, major concerns arise if trends toward eliminating tenured positions continue in favor of contingent appointments.

First, other personnel would need to be hired to complete the work, particularly in the area of service. This could both actually raise the cost of higher education and limit the expertise needed to complete the work (e.g., Massy, 2004). Many tenure decisions are not based on service, although faculty are expected to engage in it as committee work. These faculty engage in activities because they support the mission of the institution. Contingent faculty, on the other hand, may require additional payment for participating in service activities because they are usually paid only for teaching activities. This would require institutions to incur additional costs to hire individuals to do the work of these committees.

Second, if part-time faculty and/or contingent faculty (with three year) contracts are used for service, the quality of work should be questioned. Quality service in the form of student advising, committee work, and professional development depend upon collegial involvement. Kavanaugh (2000) referred to contingent faculty as "virtual non-citizens within the university community" to participate in its operations (p. 27). Therefore, quality of work and loyalty to the institution can be questioned.

\section{Recommendations for Future Research}

This study examined how faculty appointments related to the traditional theoretical framework of teaching, research, and service. Based on the 2004 NSOPF data, the results indicated that contingent faculty consistently perform lower in traditional areas of higher education: (a) to provide instruction; (b) to promote inquiry and advance knowledge; and (c) to provide professional expertise (Lynton, 1995; Seligman \& Lovejoy, 1915). Several recommendations can be made for further investigation into these issues.

First, over the past few years, one issue that may affect faculty activity is the increase of online education. In 2008 online education increased $17 \%$ and on-ground education was marginal at $1.2 \%$. There were 4.6 million students who took online courses in 2008 . Over $25 \%$ of students reported that they took at least one online course (Allen \& 
Seaman, 2010). So, its popularity is growing. Researchers may want to look at how the online environment impacts faculty activity in teaching, research, and service.

Second, since the NSOPF data are from 2004, other investigations could examine the continuity of the results of this research. For example, how have teaching, research, and service activities changed over the years when contingent faculty are compared to tenure and tenure-track faculty? Data can be compared from the four cycles of the NSOPF from 1988 to 2003 to look for trends in faculty work, including consideration for the Carnegie Classification of the institutions.

Third, an inquiry into the changing role of faculty could be examined. Upon further pressure from the public for better higher education accountability (Schmidtlein \& Berdahl, 2005), a clearer picture of the role of faculty should be examined. It is possible that faculty no longer fit within the traditional theoretical framework of teaching, research, and service. Institutions may be prone to redefine faculty roles according to economic impact (Harcleroad \& Eaton, 2005) versus traditional activities.

Finally, the notion that colleges and universities becoming more reliant on contingent faculty (Gappa et al., 2007) leads to another question. What other activities are contingent faculty involved in, if they are not participating as much in the traditional roles of faculty, as this research indicates? Ancillary to this question is, how do these activities contribute to the overall mission of higher education as well as the mission of individual institutions? Additionally, if the trend continues to rely on contingent faculty and the research shows they are underperforming in teaching, research, and service, is the traditional foundation of higher education threatened?

\section{Summary}

The study was designed to get a better look at how appointments affected faculty productivity. The results indicated that tenured and tenure-track faculty far outperform other faculty in the traditional areas of teaching, research, and service even though institutions continue to replace them with contingent faculty. It is disconcerting that increased use of contingent faculty quite possibly could challenge the mission of higher education as one that has sought for a century to promote inquiry and advance the sum of human knowledge (research), provide general instruction to the students (teaching), and develop experts for various branches of the public (service) through its faculty to provide instruction, to promote inquiry and advance knowledge, and to provide professional expertise.

\section{References}

1940 Statement of Principles on Academic Freedom and Tenure. (n.d.). Retrieved from http://www.aaup.org/AAUP/pubsres/policydocs/contents/1940statement.htm

Allen, E. I., \& Seaman, J. (2010). Learning on demand: Online education in the United States, 2009. Babson Survey Research Group. Retrieved from http://www.sloanc.org/publications/survey/pdf/learningondemand.pdf

Allen, H. E. (1996). Faculty workload and productivity in the 1990s: Preliminary findings. The NEA 1996 Almanac of Higher Education. Retrieved from http://www2.nea.org/he/healma96/index.html

Allen, H. E. (2000). Tenure: Why faculty, and the nation, need it. Thought \& Action, 16(1), 95-110.

Alshare, K.A., Wenger, J., \& Miller, D. (2007). The role of teaching, scholarly activities, and service on tenure and promotion, and merit pay decisions: Deans' Perspectives. Academy of Educational Leadership Journal, 11(1), 53-68. Retrieved from http://ehis.ebscohost.com

American Association of University Professors. (1915). 1915 Declaration of Principles on Academic Freedom and Academic Tenure. AAUP Bulletin, 1(1), 17-39.

American Association of University Professors (AAUP) website. Retrieved from http://www.aaup.org/aaup

American Association of University Professors (AAUP). (1993). Committee G on Part-time and non-tenure track appointments. The status of non-tenure-track faculty. Academe, 79(4), 39-46. Retrieved from http://ehis.ebscohost.com

American Association of University Professors. 1940 Statement of Principles on Academic Freedom and Tenure. Retrieved from http://www.aaup.org/AAUP/pubsres/policydocs/1940statement.htm

American Association of University Professors. Background Facts on Contingent Faculty. Retrieved from http://www.aaup.org/AAUP/issues*/contingent/contingentfacts.htm

American Association of University Professors. (2003). Contingent Appointments and the Academic Profession. Retrieved from http://www.aaup.org/AAUP/pubsres/policydocs/ contents/conting-stmt.htm 
American Association of University Professors. Issues in Higher Education: Tenure. Retrieved from http://www.aaup.org/AAUP/issues/tenure.htm

Bain, K. (2004). What the best college teachers do. Cambridge: Harvard University Press.

Baldwin, R. G., \& Chronister, J. L. (2001). Teaching without tenure: Policies and practices for a new era. Baltimore: The John Hopkins University Press.

Becker, W. E., \& Kennedy, P. E. (2006). The influence of teaching on research in economics. Southern Economic Journal, 72(3), 747-759. http://dx.doi.org/10.2307/20111845

Benjamin, E. (2003). Reappraisal and implications for policy and research. New Directions for Higher Education, 123, 79-113. http://dx.doi.org/10.1002/he.123

Berger, A., Kirshstein, R., \& Rowe, E. (2001). Institutional policies and practices: Results from the 1999 National Study of Postsecondary Faculty, Institution Survey. Education Statistics Quarterly, 3, 1-114. Retrieved from http://nces.ed.gov/pubsearch/pubsinfo.asp?pubid=2001201

Blackburn, R. T., \& Lawrence, J. H. (1995). Faculty at work: Motivation, expectation, satisfaction. Baltimore: The Johns Hopkins University Press.

Bland, C. J., Center, B. A., Finstad, D. A., Risbey, K. R., \& Staples, J. (2006). The impact of appointment type on the productivity and commitment of full-time faculty in research and doctoral institutions. The Journal of Higher Education, 77(1), 89-123. http://dx.doi.org/10.1353/jhe.2006.0002

Boyer, E. L. (1990). Scholarship reconsidered: Priorities of the professoriate. Princeton, NJ: Carnegie Foundation for the Advancement of Teaching.

Brand, M. (2002). Full time, non-tenure appointments: A case study. Peer Review, 5(1), 13-21. Retrieved from http://ehis.ebscohost.com

Burke, L. A., \& Rau, B. (2010). The research-teaching gap in management. Academy of Managements Learning \& Education, 9(1), 132-143. http://dx.doi.org/10.5465/AMLE.2010.48661196

Colbeck, C. L. (2001). Integration: Evaluating faculty work as a whole. In C. L. Colbeck (Ed.). Evaluating faculty performance, (pp. 43-52). San Francisco: Jossey-Bass.

Colbeck, C. L. (2004). A cybernetic systems model of teaching and research production: Impact of disciplinary differences. Invited speaker at the International Colloquium on Research and Teaching: Closing the Divide? Sponsored by Southampton Institute and the University of Southampton, United Kingdom. Retrieved from http://www.cirtl.net/files/Colbeck_Cybernetic\%20Systems_2004.pdf

Cross, J. G., \& Goldenberg, E. N. (2002). Why hire non-tenure-track faculty? Peer Review, 5(1), 25-28. Retrieved from http://ehis.ebscohost.com

Curtis, J., \& Jacobe, M. (2006). AAUP Contingent Faculty Index 2006. Washington, DC: American Association of University Professors.

Dawson, G., \& Burke, L. A. (2008). Closing the research-teaching gap in human resource management. Journal of Human Resources Education, 2(1/2), 1-8.

Davis, J. R. (1993). Better teaching, more learning: Strategies for success in postsecondary settings. Phoenix: Oryx Press.

De Rond, M., \& Miller, A. N. (2005). Publish or perish: Bane or boon of academic life? Journal of Management Inquiry, 14(4), 321-329. http://dx.doi.org/10.1177/1056492605276850

Dilts, D. A., Haber, L. J., \& Bialik, D. (1994). Assessing what professors do: An introduction to academic performance appraisal in higher education. Westport: Greenwood Press.

Eligibility Procedures and Accreditation Standards for Business. (January 31, 2012). AACSB International-The Association to Advance Collegiate Schools of Business. Retrieve from http://www.aacsb.edu/accreditation/standards-busn-jan2012.pdf

Euben, D. R. (2002). Legal watch: Publish or perish: The ever-higher publications hurdle for tenure. Academe, 88(4), 78. http://dx.doi.org/10.2307/40252203

Fairweather, J. S. (2002). The mythologies of faculty productivity: Implications for institutional policy and decision making. The Journal of Higher Education, 73(1), 26-48. http://dx.doi.org/10.1353/jhe.2002.0006 
Fairweather, J. S. (2005). Beyond the rhetoric: Trends in the relative value of teaching and research in faculty salaries. The Journal of Higher Education, 76(4), 401-422. http://dx.doi.org/10.1353/jhe.2005.0027

Fairweather, J. S., \& Beach, A. L. (2002). Variations in faculty work at research universities: Implications for state and institutional policy. The Review of Higher Education, 26(1), 97-115. http://dx.doi.org/10.1353/rhe.2002.0024

Feldman, K. A. (1987). Research productivity and scholarly accomplishment of college teachers as related to their instructional effectiveness: A review and exploration. Research in Higher Education, 26(3), 227-298. http://dx.doi.org/10.1007/BF00992241

Fender, B. F., Taylor, S. W., Burke, K. G. (2011). Substitutes or complements: Teaching and scholarship for the active scholar. Journal of Applied Financial Research, 1, 50-61. Retrieved from http://ehis.ebscohost.com

Fink, L. D. (2003). Creating significant learning experiences. San Francisco: Jossey-Bass.

Finkelstein, M. J. (2001). Understanding the American academic profession. In P.G. Altbach, P. J. Gumport, \& D. B. Johnstone (Eds.), In defense of American higher education (pp. 321-351). Baltimore: Hopkins University Press.

Florestano, P. S., \& Hambrick, R. (1984). Rewarding faculty members for profession-related public service. Educational Record, 65(1), 18-21.

Fukami, C. V. (2007). The third road. Journal of Management Education, 7, 429-439. http://dx.doi.org/10.1177/1052562906298442

Gappa, J. \& Leslie, D. (1993). The invisible faculty: Improving the status of part-timers in higher education. San Francisco: Jossey-Bass.

Gappa, J. M., Austin, A. E., \& Trice, A. G. (2005). Rethinking academic work and workplaces. Change: The Magazine of Higher Learning, 37(6), 32-39. http://dx.doi.org/10.3200/CHNG.37.6.32-39

Gappa, J. M., Austin, A. E., \& Trice, A. G. (2007). Rethinking faculty work: Higher education's strategic imperative. San Francisco: Jossey-Bass.

Green, R. G. (2008). Tenure and promotion decisions: The relative importance of teaching, scholarship, and service. Journal of Social Work Education, 44(2), 117-128. http://dx.doi.org/10.5175/JSWE.2008.200700003

Haeger, J. D. (1998). Part-time faculty, quality programs, and economic realities. New Directions for Higher Education, 26(4), 81-88. http://dx.doi.org/10.1002/he.10408

Harcleroad, F. F., \& Eaton, J. S. (2005). The hidden hand. External constituencies and their impact. In P. G. Altbach, R. O. Berdahl, and P. J. Gumport (Eds.). American higher education in the twenty-first century. Social, political, and economic challenges ( $2^{\text {nd }}$ ed., pp. 253-283). Baltimore: The Johns Hopkins University Press.

Harrington, C., \& Schibik, T. (2004). Caveat emptor: Is there a relationship between part-time faculty utilization and student learning outcomes and retention? AIR professional file no. 91. Tallahassee, FL: Association of Institutional Research.

Hattie, J., \& Marsh, H. W. (1996). The relationship between research and teaching: A meta-analysis. Review of Educational Research, 66(4), 507-542. http://dx.doi.org/10.3102/00346543066004507

Huber, M. T. (1997). Community college faculty attitudes and trends, 1997 (NCPI 4 03). Stanford, CA: Stanford University.

Jacobs, F. (1998). Using part-time faculty more effectively. New Directions for Higher Education, 104, 9-18. http://dx.doi.org/10.1002/he.10401

Jeager, A. J. (2008). Contingent faculty and student outcomes. Academe, 94(6), 42-43. Retrieved from http://ehis.ebscohost.com

Jaeger, A. J., \& Hinz, D. (2008). The effects of part-time faculty on first year freshman retention: A predictive model using logistic regression. Journal of College Student Retention, 10(3), 33-53. http://dx.doi.org/10.2190/CS.10.3.b

Kavanaugh, P. (2000). A vision of democratic governance in higher education: The stakes of work in academia. Social Policy, 30(4), 24-30. Retrieved from http://ehis.ebscohost.com

Luchs, C., Seymoure, S., \& Smith, W. (2012). How important is service in the promotion and tenure process? Research in Higher Education, 15, 1-11. Retrieved from http://www.aabri.com/manuscripts/111016.pdf

Lynton, E. A. (1995). Making the case for professional service. American Association for Higher Education. Washington, D.C. 
Lynton, E. A., \& Elman, S. E. (1987). New priorities for the university. San Francisco: Jossey-Bass.

Massy, W., \& Wilger, A. K. (1995). Improving productivity: What faculty think about it and its effects on quality. Change, 27(4), 10-20. http://dx.doi.org/10.1080/00091383.1995.9936431

Massy, W. F. (2004). Markets in higher education. Higher Education Dynamics, 6, 13-35. http://dx.doi.org/10.1007/1-4020-2835-0_2

McKeachie, W. J., \& Svinicki, M. (2006). McKeachie's teaching tips: Strategies, research, theory for college and university teachers $\left(12^{\text {th }}\right.$ ed.). Boston: Houghton Mifflin.

Meacham, J. (2002). Who should teach general education courses? Peer Review, 5(1), 11-14. Retrieved from http://ehis.ebscohost.com

Meyer, K. (1998). Faculty workload studies: Perspectives, needs, and future directions. Washington, DC: Graduate School of Education and Human Development, George Washington University.

National Center for Education Statistics, 2004 National Study of Postsecondary Faculty (NSOPF: 04) Methodology Report, NCES 2006179, by Ruth Heuer, Brian Kuhr, Mansour Fahimi, T.R. Curtin, Marjorie Hinsdale, Lisa Carley-Baxter, and Pat Green. Washington, D.C: U.S. Department of Education.

National Center for Education Statistics, 2004 National Study of Postsecondary Faculty (NSOPF: 04) Report on Faculty and Instructional Staff in Fall 2003, NCES 2005172, by E. Forrest Cataldi, MPR Associates, Inc.; M. Fahimi, RTI International; and E. M. Bradburn, MPR Associates, Inc. Washington, D.C: U.S. Department of Education.

National Center for Education Statistics, Instructional Faculty and Staff in Higher Education Institutions Fall 1987 and Fall 1992, NCES 97470, by Rita J. Kirshstein, Nancy Matheson, and Zhongren Jing (Pelavin). Washington, D.C: U.S. Department of Education.

National Center for Educational Statistics, Integrated Postsecondary Education Data System (IPEDS), Changes in Staff Distribution and Salaries of Full-Time Employees in Postsecondary Institutions: Fall 1993-2003, NCES 2006152, by Xiaojie Li. Washington, D.C: U.S. Department of Education.

National Center for Educational Statistics, Institutional Policies and Practices Regarding Postsecondary Faculty: Fall 2003, NCES 2007157, by Stephanie C. Nevill and Ellen M. Bradburn. Washington, D.C: U.S. Department of Education.

National Center for Education Statistics, National Survey of Postsecondary Faculty. 1999 (NSOPF: 99). Washington, D.C: U.S. Department of Education.

National Center for Education Statistics, National Survey of Postsecondary Faculty. 2004 (NSOPF: 04). Washington, D.C: U.S. Department of Education.

National Center for Education Statistics, Tenure Status of Postsecondary Instructional Faculty and Staff: 1992 - 98, NCES 2002210, by Basmat Parsad and Denise Glover. Washington, D.C: U.S. Department of Education.

Neill, U. S. (2008). Publish or perish, but at what cost? Journal of Clinical Investigation, 118(7), 2368. http://dx.doi.org/10.1172/JCI36371

Neumann, A., \& Terosky, A. L. (2007). To give and to receive: Recently tenured professors' experiences of service in major research universities. The Journal of Higher Education, 78(3), 282-310. http://dx.doi.org/10.1353/jhe.2007.0018

Ochoa, A. (2012). Contingent faculty: Helping or harming students. Journal of the Professoriate, 6(1), p136-151. Retrieved from http://jotp.icbche.org/2012/6_1_Ochoa_136_finalBBJ.pdf

Park, S. M. (1996). Research, teaching, and service: Why shouldn't women's work count? The Journal of Higher Education, 67(1), 46-84. http://dx.doi.org/10.2307/2943903

Parker, L. D., Guthrie, J. \& Gray R. H. (1998). Accounting and management research: Passwords from the gatekeepers. Accounting Auditing and Accountability Journal, 11(4), 371-402. http://dx.doi.org/10.1108/09513579810231420

Paulsen, M. B., \& Feldman, K. A. (1995). Toward a reconceptualization of scholarship: A human action system with functional imperatives. The Journal of Higher Education, 66(6), 615-640. http://dx.doi.org/10.2307/2943833 
Popovich, N. G., \& Abel, S. R. (2002). The need for a broadened definition of faculty scholarship and creativity. American Journal of Pharmaceutical Education, 66(1), 59-65. http://dx.doi.org/aj660110.pdf

Reid, J. R. (2008). Community college dilemma: Adjunct faculty. Community \& Junior College Libraries, 14(4), 295-298. http://dx.doi.org/10.1080/02763910802336456

Rhoades, G. (1996). Reorganizing the faculty workforce for flexibility: Part-time professional labor. The Journal of Higher Education, 67(6), 626-659. http://dx.doi.org/10.2307/2943815

Rosenthal, J. T., Cogan, M. L., Marshall, R., Meiland, J. W., Wion, P. K., \& Molotsky, I. F. (1994). Report: The work of faculty: Expectations, priorities, and rewards. Academe, 80, 35-48. Retrieved from http://ehis.ebscohost.com

Roworth, W. W. (1997). Why is tenure being targeted for attack? Retrieved from http://www.aaup2.org/publications/Footnotes/FN97/ FNWRWART.HTM

Schmidtlein, F., \& Berdahl, R. O. (2005). Autonomy and accountability: Who controls academe? In P. G. Altbach, R. O. Berdahl, \& P. J. Gumport (Eds.), American higher education in the twenty-first century: Social, political, and economic challenges ( $2^{\text {nd }}$ ed., pp. 71-90). Baltimore: Hopkins University Press.

Schuster, J. H. (2003). The faculty makeover: What does it mean for students? New Directions for Higher Education, 123, 15-22. http://dx.doi.org/10.1002/he.116

Schuster, J. H., \& Finkelstein, M. J. (2006). On the brink: Assessing the status of the American faculty. Thought \& Action, Fall, 51-62. Retrieved from http://www2.nea.org/he/tanda.html

Scott, J. C. (2006). The mission of the university: Medieval to postmodern transformations. The Journal of Higher Education, 77(1), 1-39. http://dx.doi.org/10.1353/jhe.2006.0007

Seligman, E., \& Lovejoy, A. (1915). AAUP 1915 Declaration of Principles. Retrieved from http://www.akronaaup.org/documents/AAUP1915.pdf

Singell, L. Jr., Lillydahl, J., \& Singell, L. (1996). Will changing times change the allocation of faculty time? Journal of Human Resources, 31(2), 429 - 449. http://dx.doi.org/10.2307/146070

Terpstra, D. E., \& Honoree, A. L. (2009). The effects of different teaching, research, and service emphases on individual and organizational outcomes in higher education institutions. Journal of Education in Business, 84(3), 169-176. http://dx.doi.org/10.3200/JOEB.84.3.169-176

Thedwell, K. (2008). Nontenure-track faculty: Rising numbers, lost opportunities. New Directions for Higher Education, 143, 11-19. http://dx.doi.org/10.1002/he.308

Thompson, K. (2003). Contingent faculty and student learning: Welcome to the strativersity. New Directions in Higher Education, 123, 41 - 47. http://dx.doi.org/10.1002/he.119

Townsend, R. B. (2003). Changing relationships, changing values in the American classroom. New Directions in Higher Education, 123, 23 - 32. http://dx.doi.org/10.1002/he.117

Umbach, P. D. (2007). How effective are they? Exploring the impact of contingent faculty on undergraduate education. The Review of Higher Education, 30(2), 91-123. http://dx.doi.org/10.1353/rhe.2006.0080 
Table 1. Chi-Square of Tenure Status by Teaching Structure

\begin{tabular}{|c|c|c|c|c|}
\hline \multirow{3}{*}{$\begin{array}{l}\text { Teaching } \\
\text { Structure }\end{array}$} & \multicolumn{4}{|c|}{ Tenure Status } \\
\hline & \multicolumn{2}{|c|}{ Tenured Tenure-Track } & \multirow{2}{*}{$\begin{array}{l}\text { Contingent } \\
\qquad \begin{array}{r}\text { Mean } \\
S E\end{array}\end{array}$} & \multirow{2}{*}{$\begin{array}{l}\text { No Tenure System } \\
\text { Mean } \\
S E\end{array}$} \\
\hline & $\begin{array}{l}\text { Mean } \\
S E\end{array}$ & $\begin{array}{l}\text { Mean } \\
S E\end{array}$ & & \\
\hline $\begin{array}{l}\text { Number of classes } \\
\text { taught for credit }\end{array}$ & $\begin{array}{l}2.50 \\
0.03\end{array}$ & $\begin{array}{l}2.50 \\
0.03\end{array}$ & $\begin{array}{l}1.60 \\
0.02\end{array}$ & $\begin{array}{l}2.70 \\
0.10\end{array}$ \\
\hline $\begin{array}{l}\text { Number of weeks } \\
\text { taught }\end{array}$ & $\begin{array}{c}13.70 \\
0.05\end{array}$ & $\begin{array}{c}13.70 \\
0.08\end{array}$ & $\begin{array}{c}13.40 \\
0.07\end{array}$ & $\begin{array}{c}13.60 \\
0.13\end{array}$ \\
\hline $\begin{array}{l}\text { Number of credits } \\
\text { per course }\end{array}$ & $\begin{array}{l}3.30 \\
0.02\end{array}$ & $\begin{array}{l}3.20 \\
0.03\end{array}$ & $\begin{array}{l}3.10 \\
0.02\end{array}$ & $\begin{array}{l}3.20 \\
0.05\end{array}$ \\
\hline $\begin{array}{l}\text { Number of hours } \\
\text { taught }\end{array}$ & $\begin{array}{l}4.00 \\
0.05\end{array}$ & $\begin{array}{l}3.90 \\
0.07\end{array}$ & $\begin{array}{l}4.20 \\
0.06\end{array}$ & $\begin{array}{l}4.70 \\
0.14\end{array}$ \\
\hline $\begin{array}{l}\text { Number of } \\
\text { students enrolled }^{2}\end{array}$ & $\begin{array}{l}36.70 \\
0.60\end{array}$ & $\begin{array}{c}32.90 \\
0.62\end{array}$ & $\begin{array}{c}26.40 \\
0.35\end{array}$ & $\begin{array}{c}23.60 \\
0.57\end{array}$ \\
\hline $\begin{array}{l}\text { Only graduate/ } \\
\text { first professional }\end{array}$ & $\begin{array}{l}16.60 \\
0.50\end{array}$ & $\begin{array}{c}17.40 \\
0.70\end{array}$ & $\begin{array}{c}12.20 \\
0.40\end{array}$ & $\begin{array}{l}9.90 \\
1.66\end{array}$ \\
\hline $\begin{array}{l}{ }_{1}^{1} \chi^{2}(9)=108.04, p \\
{ }^{2} \chi^{2}(9)=36.17, p \\
{ }^{3} \chi^{2}(9)=79.41, p\end{array}$ & & & & \\
\hline
\end{tabular}

Source for Mean and SE: U.S. Department of Education, National Center for Educational Statistics, 2004 National Study of Postsecondary Faculty (NSOPF: 04) 
Table 2. Percent and Standard Error of Tenure Status by Teaching Experience

\begin{tabular}{|c|c|c|c|c|}
\hline \multirow{3}{*}{$\begin{array}{l}\text { Teaching } \\
\text { Experience }\end{array}$} & \multicolumn{4}{|c|}{ Tenure Status } \\
\hline & \multicolumn{2}{|c|}{ Tenured Tenure-Track } & \multirow{2}{*}{$\begin{array}{l}\text { Contingent } \\
\qquad \begin{array}{r}\% \text { Yes } \\
S E\end{array}\end{array}$} & \multirow{2}{*}{$\begin{array}{c}\text { No Tenure System } \\
\\
\% \text { Yes } \\
S E\end{array}$} \\
\hline & $\begin{array}{l}\% \text { Yes } \\
S E\end{array}$ & $\begin{array}{l}\% \text { Yes } \\
S E\end{array}$ & & \\
\hline $\begin{array}{l}\text { Multiple-choice } \\
\text { midterm/final }\end{array}$ & $\begin{array}{l}51.50 \\
0.87\end{array}$ & $\begin{array}{c}56.80 \\
1.36\end{array}$ & $\begin{array}{c}57.80 \\
0.70\end{array}$ & $\begin{array}{c}69.60 \\
1.88\end{array}$ \\
\hline $\begin{array}{l}\text { Essay } \\
\text { midterm/final }\end{array}$ & $\begin{array}{c}56.90 \\
0.70\end{array}$ & $\begin{array}{c}59.30 \\
1.13\end{array}$ & $\begin{array}{c}46.40 \\
0.83\end{array}$ & $\begin{array}{c}46.70 \\
1.55\end{array}$ \\
\hline $\begin{array}{l}\text { Short answer } \\
\text { midterm/final }\end{array}$ & $\begin{array}{c}58.40 \\
0.81\end{array}$ & $\begin{array}{c}65.30 \\
1.23\end{array}$ & $\begin{array}{c}53.50 \\
0.76\end{array}$ & $\begin{array}{c}57.50 \\
1.71\end{array}$ \\
\hline $\begin{array}{l}\text { Use of writing } \\
\text { assignments }\end{array}$ & $\begin{array}{c}75.30 \\
0.59\end{array}$ & $\begin{array}{c}79.70 \\
0.93\end{array}$ & $\begin{array}{c}67.60 \\
0.67\end{array}$ & $\begin{array}{c}70.10 \\
1.43\end{array}$ \\
\hline $\begin{array}{l}\text { Multiple drafts } \\
\text { for writing }\end{array}$ & $\begin{array}{c}42.50 \\
0.79\end{array}$ & $\begin{array}{c}45.20 \\
1.13\end{array}$ & $\begin{array}{c}33.30 \\
0.72\end{array}$ & $\begin{array}{c}33.60 \\
1.66\end{array}$ \\
\hline $\begin{array}{l}\text { Oral } \\
\text { presentations }\end{array}$ & $\begin{array}{c}60.50 \\
0.80\end{array}$ & $\begin{array}{c}66.20 \\
1.17\end{array}$ & $\begin{array}{c}56.70 \\
0.83\end{array}$ & $\begin{array}{l}59.20 \\
1.15\end{array}$ \\
\hline $\begin{array}{l}\text { Group/team } \\
\text { projects }\end{array}$ & $\begin{array}{l}53.10 \\
0.86\end{array}$ & $\begin{array}{c}61.70 \\
1.26\end{array}$ & $\begin{array}{c}49.60 \\
0.99\end{array}$ & $\begin{array}{l}55.60 \\
1.99\end{array}$ \\
\hline $\begin{array}{l}\text { Student peer } \\
\text { evaluations }\end{array}$ & $\begin{array}{c}34.00 \\
0.85\end{array}$ & $\begin{array}{c}42.70 \\
1.17\end{array}$ & $\begin{array}{c}36.40 \\
0.40\end{array}$ & $\begin{array}{l}38.40 \\
1.66\end{array}$ \\
\hline $\begin{array}{l}\text { Service/community } \\
\text { project learning }\end{array}$ & $\begin{array}{l}24.50 \\
0.67\end{array}$ & $\begin{array}{c}31.90 \\
1.10\end{array}$ & $\begin{array}{c}25.60 \\
0.63\end{array}$ & $\begin{array}{l}31.90 \\
1.32\end{array}$ \\
\hline $\begin{array}{l}\text { Use of websites } \\
\text { for teaching }\end{array}$ & $\begin{array}{c}49.50 \\
0.67\end{array}$ & $\begin{array}{c}45.50 \\
0.80\end{array}$ & $\begin{array}{c}69.20 \\
0.62\end{array}$ & $\begin{array}{l}62.70 \\
2.06\end{array}$ \\
\hline
\end{tabular}

Source for Mean and SE: U.S. Department of Education, National Center for Educational Statistics, 2004 National Study of Postsecondary Faculty (NSOPF: 04) 
Table 3. Weighted Means and Standard Errors of Research Activity by Tenure Status

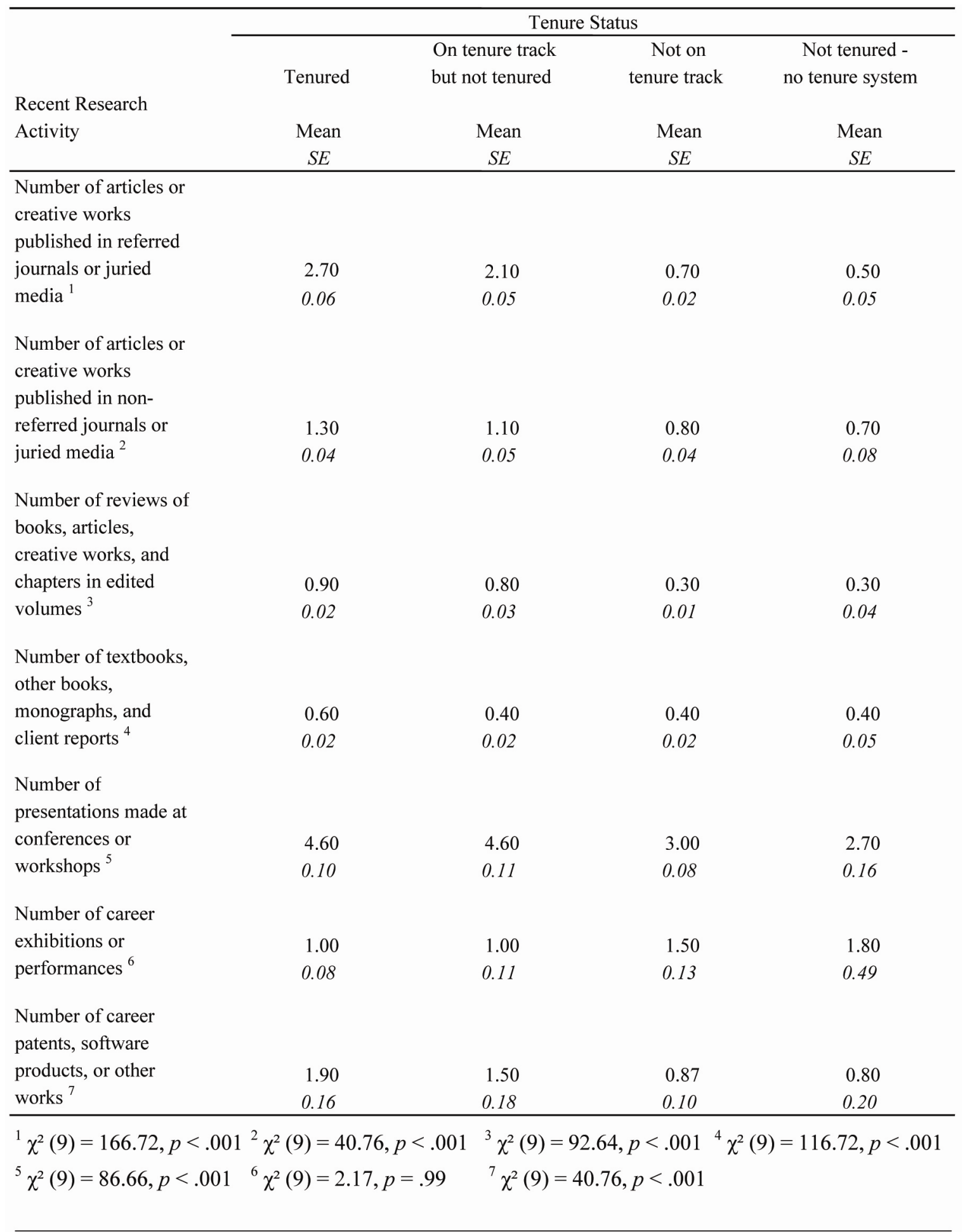

Source: U.S. Department of Education, National Center for Educational Statistics, 2004 National Study of Postsecondary Faculty (NSOPF: 04). 
Table 4. Weighted Means and Standard Errors of Service Activity by Tenure Status

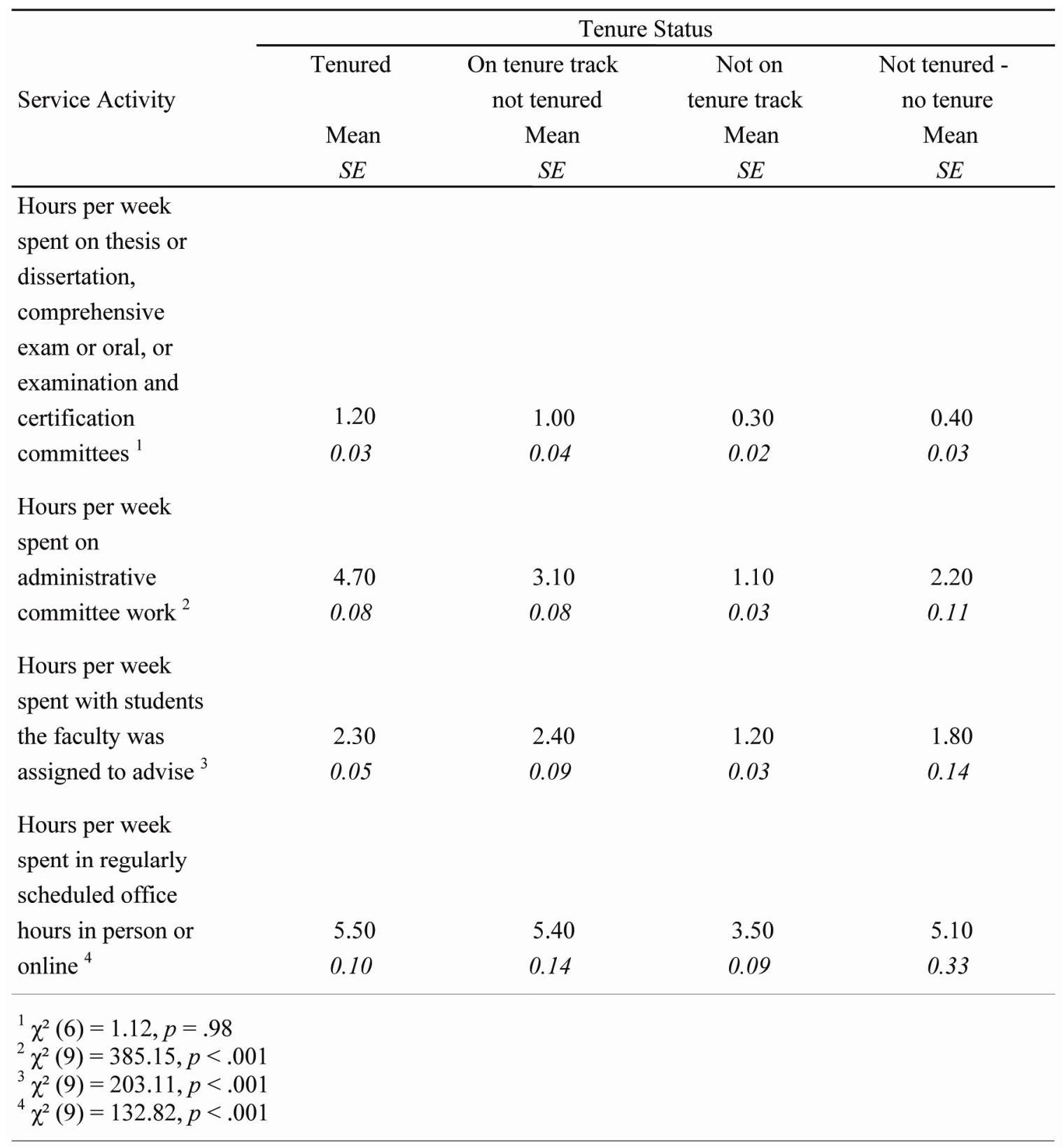

Source: U.S. Department of Education, National Center for Educational Statistics, 2004 National Study of Postsecondary Faculty (NSOPF: 04). 